\title{
Fractional Calculus-based Modelling of Membrane Filtration
}

\author{
C. Mesli, ${ }^{a, b}$ M. Laidi, ${ }^{*}$ S. Hanini, ${ }^{a}$ A. Adda, ${ }^{a}$ \\ M. Moussaoui, and M. Hentabli ${ }^{\mathrm{a}, \mathrm{d}}$ \\ a Laboratory of Biomaterials and Transfer Phenomena, University of Médéa, Algeria \\ b University Djilali Bounaama Khemis Miliana, Algeria \\ c University of Bouira, Bouira, Algeria \\ ¿ Laboratory Quality Control, Physico-Chemical Department, Antibiotical Saidal of Médéa, Algeria
}

\begin{abstract}
The aim of this work was to model the deep bed and cake filtration process using an alternative approach based on a fractional calculus (FC). The considered experimental data in this study were extracted from published studies. The data used in FC models contained two inputs - initial concentration and time, and volume of filtrate as an output. The FC kinetic constants were tuned by fitting the experimental and predicted data through Dragonfly algorithm implemented in MATLAB programming software. The performance of the developed models was assessed using different metrics by comparing the experimental against the predicted data. The developed fractional model with $n^{\text {th }}$ order presented very acceptable metrics in comparison to the pseudo- $n^{\text {th }}$ order and displayed strong potential for estimating the volume of filtrate.
\end{abstract}

\section{Keywords}

Fractional calculus, Dragonfly algorithm, membrane filtration

\section{Introduction}

Fractional calculus (FC) and its applications are becoming a fruitful field of research used to enhance the quality of the ordinary calculus. FC can deal with integrals and derivatives to an arbitrary order (real or complex). FC are good data fitting, non-locality description and easy-to-use, and disadvantages include physical interpretation, parameters determination, and three-dimensional analysis. ${ }^{1}$

Recently, several works have presented the powerful fitting tool to model the behaviour of numerous chemical engineering processes, in particular, flotation kinetics, ${ }^{2}$ drying processes, ${ }^{1,3-10}$ chaotic systems, ${ }^{11}$ extraction processes, ${ }^{12}$ pharmacokinetic, ${ }^{13}$ transport phenomena, ${ }^{14-16}$ and biochemical reactions. ${ }^{17}$ To the best of our knowledge, there is no work related to membrane filtration modelling using fractional calculus.

The novelty of this work is in using fractional calculus hybrid with recent optimisation algorithm to model the membrane filtration process in comparison to the conventional modelling.

\section{Adsorption kinetics fractional modelling}

Various physical or pseudo laws have been presented in literature based on the phenomenological hypotheses to model the adsorption process. ${ }^{18}$ These hypotheses can cause a deviation of the mathematical solution compared to the experimental data set. Recently, a new approach has been proposed by Adda et al. ${ }^{18}$, overcoming certain hypotheses and addressing the filtration as adsorption. In order to take into account the change in filtration rate over time, assuming that the chemical spaces present in the feed can be adsorbed by the membrane and/or by the cake formed, the adsorption rate is given by the $n^{\text {th }}$ pseudo-order expression as follows: ${ }^{18}$

$$
q(t)=k_{n}\left(q_{\max }-q_{t}\right)^{n}
$$

Letter $n$ in Eq. (1) is the real number $\left(n \in R^{+}\right), q(t)$ and $q_{\max }$ are the adsorbed amounts of a chemical substance at time $t$ and the maximum adsorption capacity of the membrane $\left(\mathrm{mg} \mathrm{g}^{-1}\right)$, and $k_{\mathrm{n}}$ is the reaction rate constant $\left[(\mathrm{mg} / \mathrm{g})^{1-n} \mathrm{~s}^{-1}\right.$. The amount adsorbed by the membrane can also be written as follows (Eq. (2)), as it is different from that presented initially in the feed flow. ${ }^{19}$

$$
q(t) \cdot M=\delta \cdot V(t) \cdot C_{0}
$$

$M$ is the membrane weight, $V(t)$ is the cumulative filtrate volume at time $t, C_{0}$ is the initial mass concentration in the feed flow, and $\delta$ is the retention rate of the membrane $(0<\delta<1)$, where $\delta=0$ means no adsorption and $\delta=1$ means total adsorption. ${ }^{18}$ Replacing Eq. (1) in Eq. (2) gives Eq. (3) expressed as follows: ${ }^{18}$

$$
\left\{\begin{array}{c}
\frac{d V(t)}{d t}=K_{n}\left(V_{\max }-V(t)\right)^{n} \\
V(t=0)=V(0)=0 \\
\lim _{t \rightarrow \infty} V(t)=V_{\max } \\
K_{n}=k_{n} \cdot\left(\frac{\delta \cdot C_{0}}{M}\right)^{n-1}
\end{array}\right.
$$




\subsection{Fractional first order calculus-based modelling $0<a<1$ and $n=1$}

Some simplifications have been done on the Eq. (3) to facilitate its fractional solution using $v(t)=V_{\max }-V(t)$, the time derivation of this equation can lead to:

$$
\frac{\mathrm{d} V(t)}{\mathrm{d} t}=-\frac{\mathrm{d} v(t)}{\mathrm{d} t} .
$$

The Eq. 3 can be represented as follows:

$$
\left\{\begin{array}{c}
\frac{d v(t)}{d t}=-K_{1}(v(t))^{1} \\
v(0)=V_{\max } \\
K_{1}=k_{1} \cdot\left(\frac{\delta \cdot C_{0}}{M}\right)^{0}=k_{1}
\end{array}\right.
$$

The fractional representation in terms of Caputo derivative of Eq. (5) can be expressed as follows:

$$
\left\{\begin{array}{c}
\frac{\mathrm{d}^{\alpha} v(t)}{\mathrm{d}^{\alpha} t}={ }_{0} D_{t}^{\alpha} v(t)=-K_{1 f} v(t) \\
v(0)=V_{\max }
\end{array}\right.
$$

0 and $t$ are the limits of the operation, and $\alpha$ is the fractional order. Eq. (6) is solved using direct and inverse Laplace Transform, ${ }^{20,21}$ and the final solution is given in Eq. (7).

$V(t)=V_{\max }\left[1-\sum_{n=0}^{\infty} \frac{(-1)^{n} \cdot K_{1 f}^{n} \cdot t^{\alpha n}}{\Gamma(\alpha \cdot n+1)}\right]=V_{\max }\left[1-E_{\alpha}\left(-K_{1 f} \cdot t^{\alpha}\right)\right](7)$

where $\Gamma(x)$ is the Euler Gamma function, $x \in R^{+}$. This function can satisfy the following functional equations: ${ }^{22}$

$$
\begin{aligned}
& \Gamma(x+1)=x \Gamma(x) \\
& x \Gamma(x)=(x-1) ! .
\end{aligned}
$$

The Gamma function is already programmed in MATLAB software as gamma $(\mathrm{x})$. The crucial part of the fractional calculus is the optimisation of the model parameters $\left\{K_{1 f}\right.$ and $\alpha\}$. In fractional calculus, $E_{\alpha}(x)$ is the Mittag-Leffler function, which can be presented in the following form:

$$
E_{\alpha}(x)=\sum_{k=0}^{\infty} \frac{x^{k}}{\Gamma(1+\alpha k)}
$$

If $\alpha=1$ and for long drying times, the Mittag-Leffler equation converges to the exponential function based on a Taylor series and expressed by the following relation: ${ }^{1}$

$$
E_{1}(x)=\sum_{k=0}^{\infty} \frac{x^{k}}{\Gamma(1+k)}=\mathrm{e}^{\mathrm{x}} .
$$

\subsection{Fractional second order calculus-based modelling $0<a<1$ and $n=2$}

For the pseudo second order, Eq. (3) can be written as Eq. (12).

$$
\left\{\begin{aligned}
\frac{\mathrm{d} V(t)}{\mathrm{d} t} & =K_{2}\left(V_{\max }-V(t)\right)^{2} \\
V(t & =0)=V(0)=0 \\
K_{2} & =k_{2} \cdot\left(\frac{\delta \cdot C_{0}}{M}\right)^{1}
\end{aligned}\right.
$$

This equation can be simplified by change of variable $V(t)$ with $v(t)$ represented by the Eqs. (13) and (15) in the Eq. (12), the time derivation of the Eq. (13) can lead to the Eq. (14). After this change of variable, the Eq. (12) can be written as in the Eq. (16).

$$
\begin{gathered}
v(t)=\frac{1}{V_{\text {max }}-V(t)} \\
\frac{d V(t)}{d t}=\frac{1}{v(t)^{2}} \frac{d v(t)}{d t} \\
v(t)^{2}=\frac{1}{\left(V_{\max }-V(t)\right)^{2}} .
\end{gathered}
$$

Eq. (12) can be written as follows:

$$
\left\{\begin{array}{l}
\frac{d v(t)}{d t}=K_{2} \\
v(0)=\frac{1}{V_{\max }}
\end{array}\right.
$$

The fractional representation (Eq. (17)) is:

$$
\left\{\begin{array}{c}
\frac{\mathrm{d}^{\alpha} v(t)}{\mathrm{d}^{\alpha} t}={ }_{0} D_{t}^{\alpha} v(t)=K_{2 f} \\
v(0)=\frac{1}{V_{\max }}
\end{array}\right.
$$

Based on a Caputo derivative, the solution of this differential equation is determined using direct and inverse Laplace Transform. Eq. (17) can be written as Eq. (18) or Eq. (19).

$$
\begin{gathered}
V(t)=\frac{1}{V_{\max }}+\frac{K_{2 f} t^{\alpha}}{\Gamma(\alpha+1)} \\
V(t)=V_{\max }\left[1-\frac{\Gamma(\alpha+1)}{\Gamma(\alpha+1)+V_{\max } K_{2 f} t^{\alpha}}\right]
\end{gathered}
$$




\subsection{Fractional $n^{\text {th }}$ order calculus-based modelling $0<a<1$ and $n=n$}

The $n^{\text {th }}$ solution of the fractional differential equation can be found using:

$$
v(t)=\frac{1}{\left(V_{\max }-V(t)\right)^{n-1}} .
$$

Eq. (3) can be expressed as presented by Eq. (21).

$$
\left\{\begin{array}{c}
\frac{d v(t)}{d t}=K_{n}(n-1) \\
v(0)=\frac{1}{V_{\max }^{n-1}} \\
K_{n}=k_{n} \cdot\left(\frac{\delta \cdot C_{0}}{M}\right)^{n-1}
\end{array}\right.
$$

The fractional representation (Eq. (22)) is:

$$
\left\{\begin{array}{c}
\frac{\mathrm{d}^{\alpha} v(t)}{\mathrm{d}^{\alpha} t}={ }_{0} D_{t}^{\alpha} v(t)=K_{n f}(n-1) \\
v(0)=\frac{1}{V_{\max }^{n-1}}
\end{array}\right.
$$

The solution of this differential equation using Caputo derivative and based on a direct and inverse Laplace transform is given as Eq. (23) or Eq. (24).

$$
\begin{gathered}
v(t)=\frac{\Gamma(\alpha+1)+(n-1) K_{n f} V_{\max }{ }^{n-1} t^{\alpha}}{\Gamma(\alpha+1) V_{\max }^{n-1}} \\
V(t)=V_{\max }\left[1-\frac{\Gamma(\alpha+1)}{\Gamma(\alpha+1)+(n-1) K_{n f} V_{\max }^{n-1} t^{\alpha}}\right]^{\frac{1}{n-1}}
\end{gathered}
$$

Eqs. (7), (19), and (24) are the newly developed fractional models for modelling the membrane filtration. If we replace $\alpha=1$ in Eqs. (7), (19), and (24) we obtain the first, second, and $n^{\text {th }}$ pseudo-order models developed in the paper. $^{18}$

\section{Results and discussion}

In this work, the data set for deep bed filtration used for the validation of the fractional models were extracted from this paper using digitizer software. ${ }^{18,23} \mathrm{DA}$ is considered a flexible optimisation method since it presents some advantages. Namely, it can work based on a few controlling parameters, ${ }^{25}$ it has been used in different domains in research or industrial applications. The fractional and the ordinary optimal values of parameters were tuned by fitting the experimental and predicted data using Dragonfly optimisation algorithm implemented in MATLAB programming software. ${ }^{24}$ The optimal values of parameters were obtained by minimization of the objective function between experimental and predicted values. Table 1 represents the expressions of the metrics used to measure performance of the developed models, i.e., the determination coefficient $\left(R^{2}\right)$, variance accounted for (VAF) metric, root mean squared error (RMSE), and mean absolute error (MAE). Generally, the value of 0 is the best for the MAE and RMSE, and the value of 1 or $100 \%$ is the best for $R^{2}$ or VAF, respectively. ${ }^{26}$ All these metrics were programmed and calculated using MATLAB software. The designed MATLAB program and the data set in Excel file used to tube the optimal values of parameters is presented within this paper as supplementary data 1 and 2 .

Table 1 - Expressions of statistical indicators

\begin{tabular}{c|c}
\hline Names & Metric expression \\
\hline MAE & $\frac{1}{N} \sum_{i=1}^{N}\left|V_{\text {exp }, i}-V_{\text {pred, }, i}\right|$ \\
\hline RMSE & $\sqrt{\frac{\sum_{i=1}^{N}\left(V_{\text {exp }, i}-V_{\text {cal }, i}\right)^{2}}{N}}$ \\
\hline VAF & {$\left[1-\frac{\operatorname{var}\left(V_{\text {exp }}-V_{\text {cal }}\right)}{\operatorname{var}\left(V_{\text {exp }}\right)}\right] \cdot 100$} \\
\hline$R^{2}$ & $1-\frac{\sum_{i=1}^{N}\left(V_{\text {exp }, i}-V_{\text {pred, } i}\right)^{2}}{\sum_{i=1}^{N}\left(V_{\text {exp }, i}-\overline{V_{\text {exp }, i}}\right)^{2}}$ \\
\hline
\end{tabular}

Table 1 presents a comparison between fractional and ordinary models versus experimental data in terms of determination coefficient, root mean squared error, mean squared error variance accounted. In addition, all model optimal parameters are presented for the ordinary and the fractional.

Fig. 1 shows a comparison between the experimental and predicted volume by FC against time. When the curves

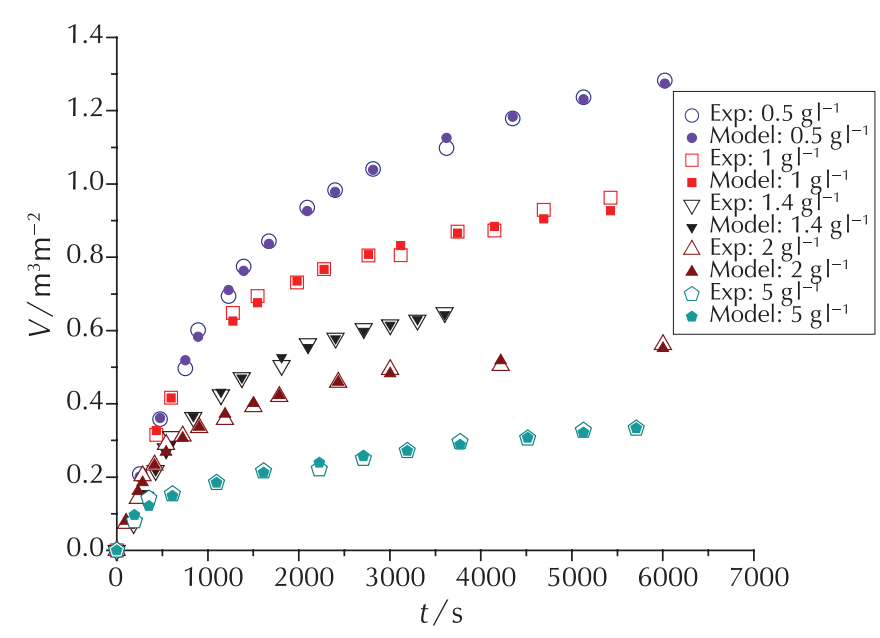

Fig. 1 -Comparison between calculated vs experimental volume against time for deep bed filtration 
Table 2 - Comparison of different metrics and kinetic parameters between fractional calculus developed in this study and ordinary models ${ }^{18}$

\begin{tabular}{|c|c|c|c|c|c|c|c|c|c|c|}
\hline \multirow[b]{2}{*}{ Concentration } & \multicolumn{2}{|c|}{$c=0.5 \mathrm{gl}^{-1}$} & \multicolumn{2}{|c|}{$c=1 \mathrm{gl}^{-1}$} & \multicolumn{2}{|c|}{$C=1.4 \mathrm{gl}^{-1}$} & \multicolumn{2}{|c|}{$C=2 \mathrm{gl}^{-1}$} & \multicolumn{2}{|c|}{$C=5 \mathrm{gl}^{-1}$} \\
\hline & Ordinary $^{18}$ & $\begin{array}{l}\text { Fractional } \\
\text { (This work) }\end{array}$ & Ordinary $^{18}$ & $\begin{array}{c}\text { Fractional } \\
\text { (This work) }\end{array}$ & Ordinary $^{18}$ & $\begin{array}{l}\text { Fractional } \\
\text { (This work) }\end{array}$ & Ordinary $^{18}$ & $\begin{array}{l}\text { Fractional } \\
\text { (This work) }\end{array}$ & Ordinary $^{18}$ & $\begin{array}{l}\text { Fractional } \\
\text { (This work) }\end{array}$ \\
\hline$n_{1}$ & 1 & 1 & 1 & 1 & 1 & 1 & 1 & 1 & 1 & 1 \\
\hline$n_{2}$ & 2 & 2 & 2 & 2 & 2 & 2 & 2 & 2 & 2 & 2 \\
\hline$n_{\text {optimal }}$ & 1.1450 & 1.7478 & 1.5715 & 1.1841 & 1.1150 & 1.0561 & 1.9561 & 1.0571 & 2.0834 & 2 \\
\hline$k_{1} / \min ^{-1}$ & 3.3590 & 0.0012 & 8.4220 & 0.0210 & 5.3800 & 0.0010 & 3.9720 & 0.0056 & 3.3740 & 0.0039 \\
\hline$k_{2} / \mathrm{mg}\left(\mathrm{g} \mathrm{min}^{-2}\right)$ & $8.9100 \cdot 10^{-4}$ & $2.7240 \cdot 10^{-4}$ & $1.6000 \cdot 10^{-3}$ & $2.4839 \cdot 10^{-4}$ & $2.6000 \cdot 10^{-3}$ & $3.2440 \cdot 10^{-4}$ & $3.1000 \cdot 10^{-3}$ & 0.0046 & $4.4000 \cdot 10^{-3}$ & 0.0046 \\
\hline $\begin{array}{c}k_{\text {optimal }} / \\
\left(\mathrm{mgg}^{-1}\right)^{-(1-n)} \mathrm{s}^{-1}\end{array}$ & $6.6900 \cdot 10^{-4}$ & 0.0014 & $1.1000 \cdot 10^{-3}$ & 4.0968 & $1.1000 \cdot 10^{-3}$ & 2.9937 & $2.9000 \cdot 10^{-3}$ & \begin{tabular}{|l|l|} 
& 12.3290 \\
\end{tabular} & $5.0000 \cdot 10^{-3}$ & 0.0012 \\
\hline$\alpha_{1 f}$ & 1 & 0.8994 & 1 & 0.8712 & 1 & 1.0441 & 1 & 0.7284 & 1 & 0.7873 \\
\hline$\alpha_{2 f}$ & 1 & 1.0758 & 1 & 1.2747 & 1 & 1.2418 & 1 & 0.8541 & 1 & 0.9920 \\
\hline$\alpha_{1 \mathrm{nf}}$ & 1 & 0.9389 & 1 & 0.6685 & 1 & 0.6909 & 1 & 0.4784 & 1 & 0.3905 \\
\hline$R_{1}{ }^{2}$ & 0.3130 & 0.9982 & 0.5400 & 0.9823 & 0.2550 & 0.9080 & 0.2890 & 0.9914 & 0.4130 & 0.9592 \\
\hline$R_{2}^{2}$ & 0.9780 & 0.9888 & 0.9750 & 0.9822 & 0.9720 & 0.9964 & 0.9890 & 0.9927 & 0.9520 & 0.9899 \\
\hline$R_{\text {optimal }}^{2}$ & 0.9970 & 0.9980 & 0.9830 & 0.9830 & 0.9930 & 0.9989 & 0.9890 & 0.9948 & 0.9530 & 0.9904 \\
\hline $\mathrm{RMSE}_{1}$ & 0.2850 & 0.0158 & 0.1910 & 0.0352 & 0.1510 & 0.0642 & 0.1270 & 0.0147 & 0.0740 & 0.0194 \\
\hline $\mathrm{RMSE}_{2}$ & 0.0494 & 0.0127 & 0.0413 & 0.0351 & 0.0290 & 0.0123 & 0.0171 & 0.0135 & 0.0225 & 0.0210 \\
\hline $\mathrm{RMSE}_{\text {optimal }}$ & 0.0208 & 0.0125 & 0.0364 & 0.0316 & 0.0171 & 0.0091 & 0.0171 & 0.0114 & 0.0215 & 0.0094 \\
\hline $\mathrm{MAE}_{1}$ & 0.5010 & 0.0128 & 0.2980 & 0.0250 & 0.3640 & 0.0392 & 0.3780 & 0.0125 & 0.4460 & 0.0158 \\
\hline $\mathrm{MAE}_{2}$ & 0.4210 & 0.0096 & 0.2570 & 0.0237 & 0.4190 & 0.0086 & 0.4090 & 0.0113 & 0.4450 & 0.0174 \\
\hline $\mathrm{MAE}_{\text {optimal }}$ & 0.3870 & 0.0099 & 0.2690 & 0.0203 & 0.3930 & 0.0064 & 0.3185 & 0.0089 & 0.2141 & 0.0065 \\
\hline $\mathrm{VAF}_{1} / \%$ & & 99.8200 & & 98.2300 & & 90.8100 & & 99.1400 & & 96.0400 \\
\hline $\mathrm{VAF}_{2} / \%$ & & 99.8800 & & 98.2300 & & 99.6400 & & 99.2700 & & 99.0600 \\
\hline $\mathrm{VAF}_{\text {optimal }} / \%$ & & 99.8000 & & 98.5700 & & 99.8900 & & 99.4800 & & 99.0400 \\
\hline$V_{\max }$ & & 1.3803 & & 1.1841 & & 0.9002 & & 0.7781 & & 0.3500 \\
\hline
\end{tabular}

are examined carefully, it can be seen that the experimental results and the fractional predictions have the same trends, and are in good agreement for the five selected concentrations. The good agreement between the experimental and the predicted values by $n^{\text {th }}$ fractional calculus was found with the concentration of $1.4 \mathrm{~g} \mathrm{I}^{-1}$ with higher determination coefficient and lower RMSE, MAE, and VAE\% $\{0.9989,0.0091,0.0064$, and 99.89$\}$ in contrast to the ordinary solution that was found with $\{0.993,0.0171$, $0.0064\}$. The higher deviation was found with the concentration of $1 \mathrm{~g} \mathrm{I}^{-1}$ with $\{0.9830,0.03165,0.020343$, and 98.57$\}$ in comparison to the experimental data with $\{0.9830,0.0364,0.2690$, and $98.57 \%\}$. Overall, according to the obtained results, it is clear that the fractional calculus can be used in deep bed filtration.

Fig. 2 shows another comparison between second and $n^{\text {th }}$ order of fractional modelling and pseudo second order of the ordinary solution in terms of RMSE, showing the flexibility of the fractional calculus to model the deep bed filtration in the range of the selected concentrations.

Fig. 3 illustrates a regression comparison between the experimental and predicted outputs values of volume fil-

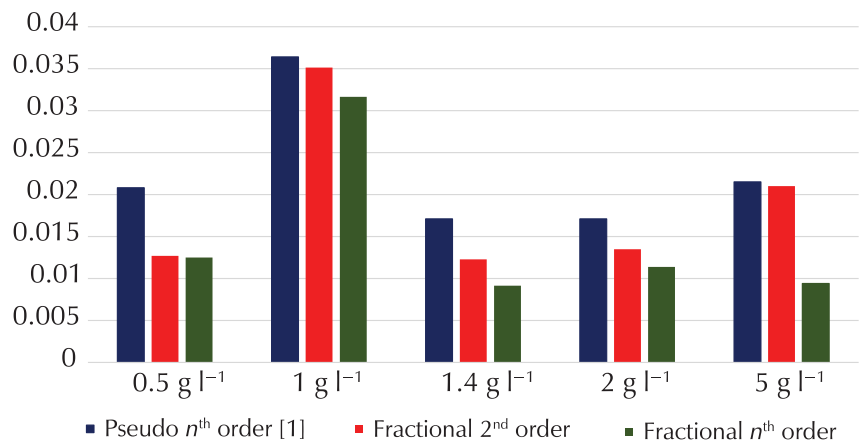

Fig. 2 - RMSE bar plot comparison of the developed models

trate for the five concentrations using $n^{\text {th }}$ fractional model. This comparison was found with an agreement vector $[\alpha$ (slope), $\beta$ (intercept), $R$ (correlation coefficient)] $=[1.0000$, $-0.0009,0.9993]$. The results reveal an overall accuracy of the developed model in correlating the total data. The prediction precision of the optimised model is appraised by its RMSE, $R$, and $R^{2}$ of a value of $0.0120,0.9993$, and 0.9986 , respectively. 


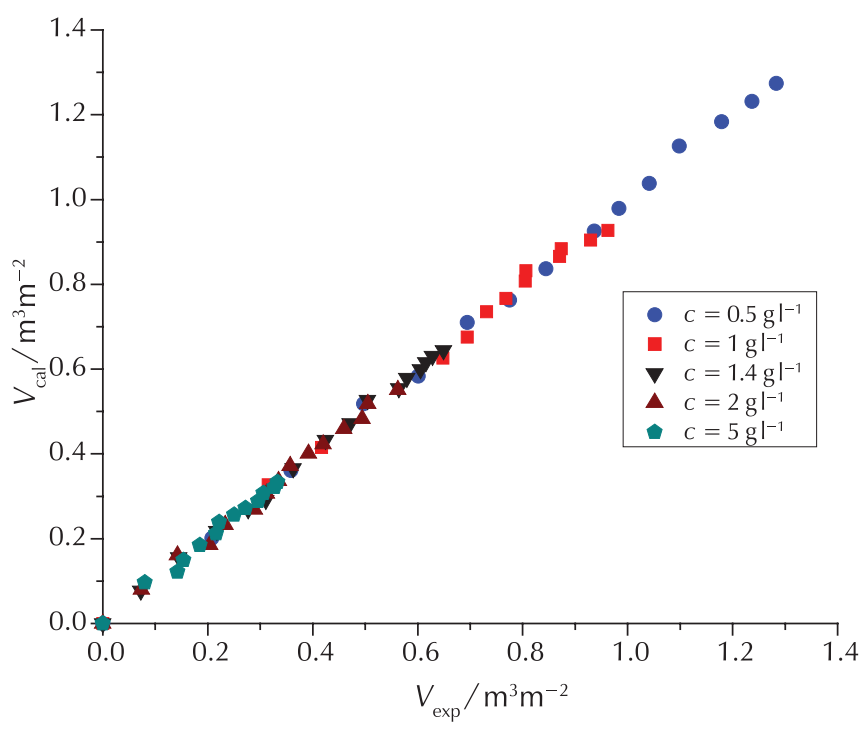

Fig. 3 - Regression plot of the calculated vs experimental volume values under the selected concentrations

An extrapolation section has been depicted in Fig. 4 to assess the performance of the best model using an external data set not used during the optimisation stage. The selected data for extrapolation were extracted from this paper representing cake filtration. ${ }^{27}$ Results showed a perfect agreement between the predictions of the fractional models and experimental data. The closeness of the model curves to the experimental data was quantified by means of determination coefficient, which was close to 1.

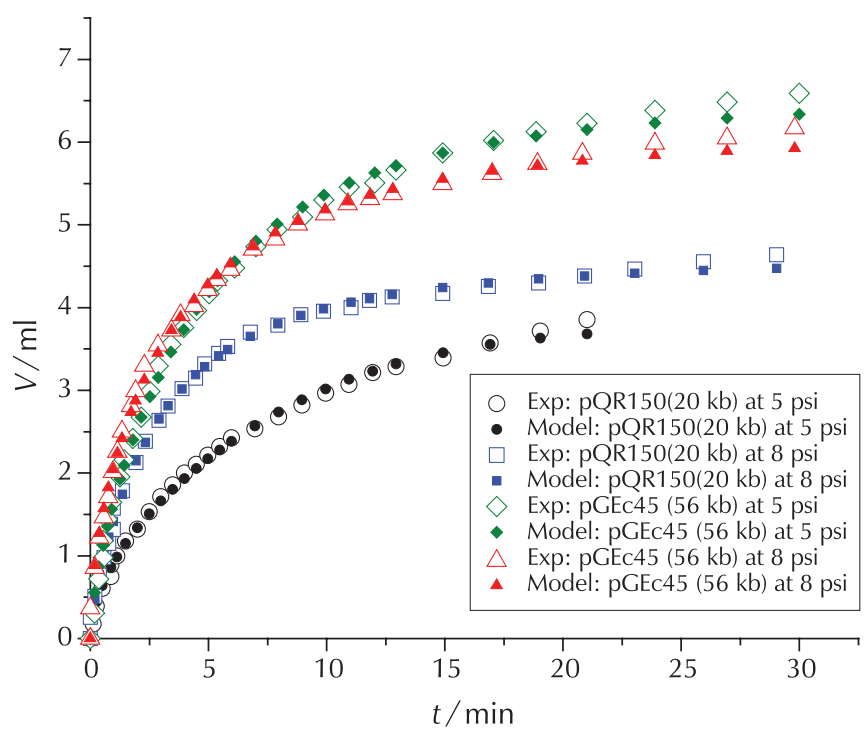

Fig. 4 - Extrapolation plot of cumulated volume filtrate vs time for cake filtration

\section{Conclusions}

The aim of this work was to model deep bed and cake filtration using an alternative approach to ordinary fractional calculus. The results showed that FC with $n^{\text {th }}$ order can fit any kinetics of the two types of membrane filtration process with high accuracy. The extrapolation phase was also conducted using another system, and the results showed that the values predicted by the $n^{\text {th }}$ order FC model follow exactly the trend of the experimental values with very low deviation under the different operating conditions.

\section{ACKNOWLEDGEMENTS}

We are most grateful to the Algerian Ministry of Higher Education and Scientific Research (DGRSDT/MESRS) (PRFU project number: A16N01UN260120180002) and the Laboratory of Biomaterials and Transfer Phenomena, Faculty of Technology, University of Médéa, Algeria. We would also like to thank the editor and the anonymous reviewers for their helpful comments.

\section{References \\ Literatura}

1. G. D. S. Matias, C. Andressa, B. Luiz, M. De Matos, The fractional calculus in studies on drying : A new kinetic semi-empirical model for drying, J. Food Process Eng. 42 (1) (2018) 1-7, doi: https://doi.org/10.1111/jfpe.12955.

2. L. Vinnett, M. Alvarez-Silva, A. Jaques, F. Hinojosa, J. Yianatos, Batch flotation kinetics: Fractional calculus approach, Miner. Eng. 77 (2015) 167-171, doi: https://doi.org/10.1016/j.mineng.2015.03.020.

3. R. Simpson, C. Ramírez, H. Nuñez, A. Jaques, S. Almonacid, Understanding the success of Page's model and related empirical equations in fitting experimental data of diffusion phenomena in food matrices, Trends Food Sci. Technol. 62 (2017) 194-201, doi: https://doi.org/10.1016/j. tifs.2017.01.003.

4. Q. Li, S. Xu, Q. Zeng, A fractional kinetic model for drying of cement-based porous materials, Dry. Technol. 34 (2016) 1231-1242, doi: https://doi.org/10.1080/07373937.2015.1 103255.

5. C. Ramírez, V. Astorga, H. Nuñez, A. Jaques, R. Simpson, Anomalous diffusion based on fractional calculus approach applied to drying analysis of apple slices: The effects of relative humidity and temperature, J. Food Process Eng. 40 (2017) 1-10, doi: https://doi.org/10.1111/jfpe.12549.

6. A. M. Asemu, N. G. Habtu, M. A. Delele, B. Subramanyam, $S$. Alavi, Drying characteristics of maize grain in solar bubble dryer, J. Food Process Eng. 43 (2020) 1-19, doi: https://doi. org/10.1111/jfpe.13312.

7. D. J. Nicolin, D. F. Rossoni, L. M. M. Jorge, Study of uncertainty in the fitting of diffusivity of Fick's Second Law of Diffusion with the use of Bootstrap Method, J. Food Eng. 184 (2016) 63-68, doi: https://doi.org/10.1016/j.jfoodeng.2016.03.024. 
8. D. J. Nicolin, L. Mario, D. M. Jorge, R. Oliveira, D. Diogo, F. Rossoni, Mathematical modeling of soybean drying by a fractional-order kinetic model, J. Food Process. Eng. 41 (2018) e12655, doi: https://doi.org/10.1111/jfpe.12655.

9. H. W. Zhou, S. Yang, S. Q. Zhang, Conformable derivative approach to anomalous diffusion, Phys. A 491 (2018) 10011013, doi: https://doi.org/10.1016/j.physa.2017.09.101.

10. M. Abdelkader, M. Laidi, S. Hanini, M. Hentabli, A grey wolf optimizer-based fractional calculus in studies on solar drying, Kem. Ind. 70 (2020) 39-47, doi: https://doi.org/10.15255/ KUI.2020.035.

11. Y. Mousavi, A. Alfi, Fractional calculus-based firefly algorithm applied to parameter estimation of chaotic systems, Chaos Soliton. Fract. 114 (2018) 202-215, doi: https://doi. org/10.1016/j.chaos.2018.07.004.

12. A. Jaques, C. Da Silva, N. Duru, T. Seal, Fractional calculus application for diffusion controlled leaching column testing, Int. J. Miner. Process. 169 (2017) 185-187, doi: https://doi. org/10.1016/j.minpro.2017.09.007.

13. I. Petráš, R. L. Magin, Simulation of drug uptake in a two compartmental fractional model for a biological system, Commun. Nonlinear Sci. 16 (2011) 4588-4595, doi: https:// doi.org/10.1016/j.cnsns.2011.02.012.

14. M. F. El Amin, A. G. Radwan, S. Sun, Analytical solution for fractional derivative gas-flow equation in porous media, Results Phys. 7 (2017) 2432-2438, doi: https://doi. org/10.1016/j.rinp.2017.06.051.

15. D. Sierociuk, A. Dzielinski, G. Sarwas, I. Petras, I. Podlubny, T. Skovranek, Modelling heat transfer in heterogeneous media using fractional calculus, Philos. T.. R. Soc. A 371 (2013), doi: https://doi.org/10.1098/rsta.2012.0146.

16. R. Simpson, C. Ramírez, V. Birchmeier, A. Almonacid, J. Moreno, $H$. Nuñez, $A$. Jaques, Diffusion mechanisms during the osmotic dehydration of Granny Smith apples subjected to a moderate electric field, J. Food Eng. 166 (2015) 204-211, doi: https://doi.org/10.1016/j.jfoodeng.2015.05.027.

17. R. Toledo-Hernandez, V. Rico-Ramirez, G. A. Iglesias-Silva, U. M. Diwekar, A fractional calculus approach to the dynamic optimization of biological reactive systems. Part I: Fractional models for biological reactions, Chem. Eng. Sci. 117 (2014) 217-228, doi: https://doi.org/10.1016/j.ces.2014.06.034.

18. A. Adda, S. Hanini, M. Abbas, M. Sediri, Novel adsorption model of filtration process in polycarbonate track-etched membrane: Comparative study, Environ. Eng. Res. 25 (2019) 479-487, doi: https://doi.org/10.4491/eer.2019.136.

19. C. Tien, B. V Ramarao, Revisiting the laws of filtration: An assessment of their use in identifying particle retention mechanisms in filtration, J. Memb. Sci. 383 (2011) 17-25, doi: https://doi.org/10.1016/j.memsci.2011.07.019.

20. D. Xue, A. Inverse Laplace transforms involving fractional and irrational operations, in: Fractional-Order Control Systems: Fundamentals and Numerical Implementations, Berlin, Boston: De Gruyter, 2017, pp. 353-356, doi: https://doi. org/10.1515/9783110497977-011.

21. F. S. Silva, D. M. Moreira, M. A. Moret, Conformable Laplace transform of fractional differential equations, Axioms 7 (2018) 1-12, doi: https://doi.org/10.3390/axioms7030055.

22. A. Almusharrf, Development of Fractional Trigonometry and an Application of Fractional Calculus to Pharmacokinetic Model, Appl. Math. Sci. 3 (1997) 455-462, doi: https://doi. org/10.1090/S0002-9904-1968-12045-2.

23. C. Tien, B. V. Ramarao, R. Yasarla, A blocking model of membrane filtration, Chem. Eng. Sci. 111 (2014) 421-431, doi: https://doi.org/10.1016/j.ces.2014.01.022.

24. H. Benimam, C. S. Moussa, M. Hentabli, S. Hanini, M. Laidi, Dragonfly-Support vector machine for regression modeling of the activity coefficient at infinite dilution of solutes in imidazolium ionic liquids using $\sigma$-profile descriptors, J. Chem. Eng. Data 65 (2020) 3161-3172, doi: https://doi. org/10.1021/acs.jced.0c00168.

25. S. Najari, S. Saeidi, G. Gróf, F. J. Keil, A. E. Rodrigues, Kinetic parameters estimation via dragonfly algorithm (DA) and comparison of cylindrical and spherical reactors performance for $\mathrm{CO}_{2}$ hydrogenation to hydrocarbons, Energ. Convers. Manage. 226 (2020), doi: https://doi.org/10.1016/j. enconman.2020.113550.

26. W. Gao, A. S. Alqahtani, A. Mubarakali, D. Mavaluru, S. khalafi, Developing an innovative soft computing scheme for prediction of air overpressure resulting from mine blasting using GMDH optimized by GA, Eng. Comput. 36 (2020) 647-654, doi: https://doi.org/10.1007/s00366-019-007205.

27. A. Affandy, E. Keshavarz-Moore, H. K. Versteeg, Application of filtration blocking models to describe fouling and transmission of large plasmids DNA in sterile filtration, J. Memb. Sci. 437 (2013) 150-159, doi: https://doi.org/10.1016/j. memsci.2013.02.055 


\title{
SAŽETAK
}

\author{
Modeliranje membranske filtracije primjenom frakcijskog računa \\ Chehrazad Mesli, a,b Maamar Laidi, ${ }^{*}$ Salah Hanini, ${ }^{a}$ Asma Adda, \\ Mohammed Moussaouic i Mohamed Hentablia,d
}

Cilj ovog rada bio je modelirati proces dubinske filtracije i filtracije kroz filtarski kolač primjenom alternativnog pristupa temeljenog na frakcijskom računu (FC). Eksperimentalni podatci koji su korišteni u ovom radu preuzeti su iz dostupnih objavljenih radova. Podatci za FC modele sadržavali su dva ulaza: početnu koncentraciju i vrijeme, te volumen filtrata kao jedini izlaz. Kinetičke konstante FC-a podešene su ugađanjem predviđenih i eksperimentalnih podataka primjenom Dragonfly algoritma implementiranog u računalnom programu MATLAB. Karakteristike razvijenih modela procijenjene su uspoređivanjem predviđenih s eksperimentalnim podatcima kroz više statističkih pokazatelja. Razvijeni frakcijski model $n$-tog reda pokazao je vrlo dobre karakteristike u usporedbi s modelom pseudo- $n$-tog reda čime je iskazao visok potencijal za primjenu u procjeni volumena filtrata.

\section{Ključne riječi}

Frakcijski račun, Dragonfly algoritam, membranska filtracija

\footnotetext{
a Laboratory of Biomaterials and Transfer Phenomena, University of Médéa, Alžir

b University Djilali Bounaama Khemis Miliana, Alžir

c University of Bouira, Bouira, Alžir

d Laboratory Quality Control, Physico-Chemical

Department, Antibiotical Saidal of Médéa, Alžir
}

Izvorni znanstveni rad Prispjelo 25. siječnja 2021. Prihvaćeno 13. travnja 2021. 